\title{
Oxovanadium(IV) Complexes with Nitrogen Donors: Synthesis, Characterisation, and Biological Activities
}

\author{
Gauri D. Bajju, ${ }^{1}$ Puja Sharma, ${ }^{1}$ Ashu Kapahi, ${ }^{1}$ Madhulika Bhagat, ${ }^{2}$ \\ Sujata Kundan, ${ }^{1}$ and Deepmala Gupta ${ }^{1}$ \\ ${ }^{1}$ Department of Chemistry, University of Jammu, Jammu, and Kashmir 180006, India \\ ${ }^{2}$ School of Biotechnology, University of Jammu, Jammu, and Kashmir 180006, India \\ Correspondence should be addressed to Gauri D. Bajju; gauribajju@gmail.com
}

Received 25 April 2013; Accepted 18 July 2013

Academic Editor: Radhey Srivastava

Copyright (C) 2013 Gauri D. Bajju et al. This is an open access article distributed under the Creative Commons Attribution License, which permits unrestricted use, distribution, and reproduction in any medium, provided the original work is properly cited.

Some oxovanadium(IV) complexes of SA/SSA and 5, 10, 15, and 20-meso-tetraphenylporphyrin $\left(\mathrm{H}_{2}\right.$ tpp) with unidentate and bidentate nitrogen donors have been synthesized and characterized by elemental analysis, conductivity measurements, magnetic susceptibility, UV-Vis, IR, mass spectroscopy, TGA/DTA, and ${ }^{1} \mathrm{H},{ }^{13} \mathrm{C}$ and ${ }^{51} \mathrm{~V}$ NMR studies to investigate the steric and electronic effects of axial ligands on the properties of porphyrins. On the basis of these studies, it has been investigated that the axial ligands bind to the sixth coordination site of the vanadium ion to form a relatively stable six-coordinate-porphyrin complex where as in the case of SA/SSA complexes the nitrogen donors bind to the equatorial position giving square pyramidal geometry. The in vitro cytotoxicity against human cancer cell lines and antimicrobial activities of the synthesized compounds have been done against various fungal and bacterial pathogens. The $[\mathrm{VO}(\mathrm{SA} / \mathrm{SSA}) \mathrm{L} / \mathrm{L}-\mathrm{L}]$ complexes were found to possess higher antibacterial, antifungal activity and in vitro cytotoxicity against human cancer cell lines than $\mathrm{VO}(\mathrm{tpp}) \mathrm{L}$ complexes.

\section{Introduction}

Macrocyclic nitrogen donor ligands [1] have received special attention because of their versatile coordination modes [2] and for their biological activities, that is, toxicity against bacterial [3] and fungal growth, anticancerous [4], and other biochemical properties [5]. Such ligands, for example, porphyrins, salicylates, and sulphosalicylates, are known to play a very important and vital role in the stability of the metal complexes with the factor of having specific cavity size, stereochemical rigidity, flexibility, and ability to coordinate with metal atom [6]. SA/SSA ligands and their complexes are widespread in nature and of considerable relevance in medicinal chemistry [7] and also in industries $[8,9]$ (e.g., in the preparation of heterometallic precursors to oxide materials). $\mathrm{VO}^{2+}$ complexes have extensive clinical applications. However, there have been no reports on the corresponding organo oxovanadium(IV) salicylates, sulphosalicylates and porphyrins, though these compounds are expected to be biomedically relevant $[10,11]$.
We report herein the synthesis of some mixed ligand complexes (containing different donor atoms) and characterisation by means of spectral and magnetic studies as well as in vitro biological assays of some of the complexes. Structural correlation of these complexes has also been made and a square pyramidal geometry around $[\mathrm{VO}(\mathrm{SA} / \mathrm{SSA}) \mathrm{L} / \mathrm{L}-\mathrm{L}]$ and an octahedral geometry around $[\mathrm{VO}(\mathrm{tpp}) \mathrm{L}]$ complexes are proposed on the basis of electronic spectroscopic studies.

\section{Materials and Methods}

All reagent grade solvents were purified by the standard procedure. Vanadyl sulphate and vanadium pentaoxide were purchased from Loba Chemie, and salicylic acid (SA) and sulfosalicylic acid (SSA) were purchased from Qualigens Chemicals and were used as received. Gravimetrically vanadium was estimated as silver orthovanadate. Carbon, hydrogen, nitrogen, and sulphur were analysed microanalytically using CHNS Analyser CHNS-932. IR spectra of the complexes over the region $4000-400 \mathrm{~cm}^{-1}$ were recorded on Perkin Elmer 
grating spectrophotometer using $\mathrm{KBr}$ discs. Electronic spectra of $[\mathrm{VO}(\mathrm{SA} / \mathrm{SSA}) \mathrm{L} / \mathrm{L}-\mathrm{L}]$ complexes were run in DMSO and those of porphyrins in different solvents on a Perkin Elmer spectrophotometer in the $200-600 \mathrm{~nm}$ range using $10^{-3} \mathrm{M}$ solution of the complexes. The MALDI mass spectra of $[\mathrm{VO}(\mathrm{SA} / \mathrm{SSA}) \mathrm{L} / \mathrm{L}-\mathrm{L}]$ complexes were recorded on Bruker Daltonics spectrophotometer whereas those of [VO(tpp)L] complexes were recorded on Bruker Daltonics spectrophotometer using positive linear high power of detection at an accelerating voltage of $20 \mathrm{KV}$ and laser power tuned depending on the sample. The ${ }^{1} \mathrm{H}$ and ${ }^{13} \mathrm{C}$ NMR spectra were recorded on a Bruker Avans $400 \mathrm{MHz}$ spectrophotometer. Molar conductivity of [VO(SA/SSA)L/L-L] complexes in DMSO at room temperature was measured by Digital Conductivity Meter Century CC 601 having conductivity cell with a cell constant of 1.1 using $10^{-3} \mathrm{M}$ solution of complexes and also magnetic measurements at room temperature were carried out by V.S.M. method. The thermogravimetric analyses (TGA) and differential thermal analyses (DTA) were performed on a Linseis STA PT-1000 in air atmosphere at a heating rate of $10^{\circ} \mathrm{C} / \mathrm{min}$.

\section{Procedure for Synthesis of [VO(SA/SSA)L/L-L] Complexes}

The VO(SA/SSA) precursors were prepared by the reaction of vanadyl sulphate $(0.40 \mathrm{~g}, 2.5 \mathrm{mM})$ with salicylic acid (SA) $(0.34 \mathrm{~g}, 2.5 \mathrm{mM}) /$ sulphosalicylic acid (SSA) $(0.54 \mathrm{~g}, 2.5 \mathrm{mM})$ and granular zinc (mesh size 20, $0.10 \mathrm{~g}, 1.5 \mathrm{mM}$ ) in $30 \mathrm{~mL}$ methanol. The reaction mixture was refluxed for one hour. The refluxing led to the formation of [VO(SA/SSA)] precursor. The complexes of $[\mathrm{VO}(\mathrm{SA} / \mathrm{SSA}) \mathrm{L}]$ with pyridines had been prepared by adding the appropriate ligand directly to the solution of this $[\mathrm{VO}(\mathrm{SA} / \mathrm{SSA})]$ precursor as

$$
\mathrm{VOSO}_{4}+\mathrm{SA}+2 \mathrm{~L} \stackrel{\mathrm{Zn} \text {, methanol }}{\longrightarrow}\left[\mathrm{VO}(\mathrm{SA})(\mathrm{L})_{2}\right]
$$

where $\mathrm{L}=\mathrm{o}$-aminopyridine and $\mathrm{o}$ and $\mathrm{m}$-methyl pyridines.

The complexes were also synthesized by using bidentate nitrogen donors such as ethylene diamine, 2,2 -bipyridyl, and 1,10-phenanthroline. The saturated solution of ligand was added dropwise to the hot reaction mixture of [VO(SA/SSA)] precursor. The addition of ligand resulted in the precipitation of complex. This reaction mixture obtained was again refluxed for fifteen minutes. The complex was filtered and dried. The colour of complexes was muddy brown and physical state was dry powder.

Consider the following:

$$
\mathrm{VOSO}_{4}+\mathrm{SA}+\mathrm{L}-\mathrm{L} \stackrel{\mathrm{Zn}, \text { methanol }}{\longrightarrow}[\mathrm{VO}(\mathrm{SA})(\mathrm{L}-\mathrm{L})]
$$

where $\mathrm{L}-\mathrm{L}=$ ethylene diamine and 1,10-phenanthroline.

Spectroscopic characterisation has been given in Tables $1-5$.

\section{Procedure for Synthesis of $[\operatorname{VO}(\operatorname{tpp}) \mathrm{L}]$ Complexes}

4.1. Step I Synthesis of 5, 10, 15, and 20-Tetraphenylporphyrin $\left[\mathrm{H}_{2} t p p\right]$. The metal-free-base $\mathrm{H}_{2}$ tpp was synthesized by the conventional method of aldehyde condensation with pyrrole and was characterized by UV-Vis and ${ }^{1} \mathrm{H}$ NMR spectroscopies using Adler and longo method [12] and and the general scheme was outlined by Menotti et al. [13] for the synthesis of $\mathrm{H}_{2} \operatorname{tpp}$ (Scheme 1).

4.2. Physical, Analytical, and Spectral Data of 5, 10, 15, and 20-Tetraphenylporphyrin $\left[\mathrm{H}_{2} t p p\right]$. Yield (purple crystalline, $60 \%)$; m. p. $453^{\circ} \mathrm{C}$; IR (KBr, cm $\left.{ }^{-1}\right): 2963(\mathrm{CH}), 3450(\mathrm{NH})$, $1637(\mathrm{C}=\mathrm{C}), 1095(\mathrm{C}-\mathrm{N})$, and $1350(\mathrm{C}=\mathrm{N}$, pyrrole $) ;{ }^{1} \mathrm{H}$ NMR $\left(\mathrm{CDCl}_{3}\right): \delta 8.84(\mathrm{~s}, 8 \mathrm{H}, \beta$-pyrrole protons), 2.79 (s, $2 \mathrm{H}$, imino protons), $8.17\left(\mathrm{~s}, 8 \mathrm{H}, \mathrm{H}_{\mathrm{o}}\right)$, and $7.6\left(\mathrm{~s}, 12 \mathrm{H}, \mathrm{H}_{\mathrm{m} . \mathrm{p}}\right)$ for meso-aryl protons; anal. calcd. for $\mathrm{C}_{44} \mathrm{H}_{30} \mathrm{~N}_{4}$ (614.75): C, 85.92; $\mathrm{H}, 4.89$; N, 9.10; found: C, 85.82; H, 4.63; N, 9.01\%.

4.3. Step II Synthesis of Oxovanadium(IV)Porphyrin [VO (tpp)] Precursor. $0.114 \mathrm{gm}$ of $\mathrm{H}_{2}$ tpp and $0.30 \mathrm{~g}$ of $\mathrm{VO}(\mathrm{acac})_{2}$ over salt bath were stirred at $290^{\circ} \mathrm{C}$ for ten minutes in a long neck round bottom flask covered with a funnel. After completion as indicated by TLC, the reaction mixture was cooled at room temperature, extracted with distilled water, and filtered through anhydrous sodium sulphate. The solvent was evaporated under vacuum to afford crude product, which was purified by column chromatography, recrystallized, and characterized (Scheme 2).

Yield (greenish); UV-Vis $\left(\mathrm{CHCl}_{3}\right): \lambda_{\max }$ (in nm) (log $\varepsilon$ ) 420(0.846) for B-band and 550(0.215) for Q-band: IR ( $\mathrm{KBr}$, $\left.\mathrm{cm}^{-1}\right): 2961(\mathrm{CH}), 1634(\mathrm{C}=\mathrm{C}), 1088(\mathrm{C}-\mathrm{N}), 1348(\mathrm{C}=\mathrm{N}),$, $(\mathrm{V}=\mathrm{O}) ;{ }^{1} \mathrm{H}$ NMR $\left(\mathrm{CDCl}_{3}\right): \delta 9.8$ (s, 8H, $\beta$-pyrrole protons), $8.49\left(\mathrm{~s}, 8 \mathrm{H}, \mathrm{H}_{\mathrm{o}}\right)$, and $7.98\left(\mathrm{~m}, 12 \mathrm{H}, \mathrm{H}_{\mathrm{m} . \mathrm{p}}\right)$ for meso-aryl protons; anal. calcd. for $\left(\mathrm{C}_{44} \mathrm{H}_{28} \mathrm{~N}_{4}\right) \mathrm{VO}$ (679.496): C, 77.76; $\mathrm{H}, 4.15 ; \mathrm{N}, 8.24 ; \mathrm{V}, 7.49$; found: C, 77.73; H, 4.14; N, 8.20; V, $7.48 \%$.

4.4. Step III Synthesis of [VO(tpp)L] Complexes. Pyridine $\left(3.211 \times 10^{-2}\right)$ (as axial ligand) and [VO(tpp)] in 1:1 molar ratio were stirred without heating. After completion of reaction as again indicated by TLC, the reaction mixture is extracted with distilled water. The extracted portion containing compound was evaporated by vacuum pump and the dried product was then dissolved in chloroform and filtered through anhydrous sodium sulphate and evaporated by vacuum pump. Finally, the purification of the product was done by column chromatography through basic alumina using chloroform as the eluent. The dried product was crystallized with chloroform and recrystallized with petroleum ether. Finally, the compound was characterized by UV-Vis and ${ }^{1} \mathrm{H}$ NMR spectra (Scheme 3 ).

UV-Vis $\left(\mathrm{CHCl}_{3}\right): \lambda_{\max }$ (in nm) (log $\varepsilon$ ) 427.6(4.742) for Bband and 559.7(4.284) and 609.8(4.109) for Q-bands; IR (KBr, $\left.\mathrm{cm}^{-1}\right)$ : $2965(\mathrm{CH}), 1652(\mathrm{C}=\mathrm{C}), 1094(\mathrm{C}-\mathrm{N}), 1344(\mathrm{C}=\mathrm{N})$, $1010(\mathrm{~V}=\mathrm{O}) ;{ }^{1} \mathrm{H}$ NMR $\left(\mathrm{CDCl}_{3}\right): \delta 9.3(\mathrm{~s}, 8 \mathrm{H}, \beta$-pyrrole protons), $8.18\left(\mathrm{~d}, 10 \mathrm{H}, J=7, \mathrm{H}_{\mathrm{o}}\right)$, and $7.95\left(\mathrm{~m}, 14 \mathrm{H}, \mathrm{H}_{\mathrm{m} . \mathrm{p}}\right)$ for 
TABLE 1: Molar conductance values of magnetic measurement, UV-bands, and $m / z$ values of complexes.

\begin{tabular}{|c|c|c|c|c|c|}
\hline Codes & Name of the complex & $\begin{array}{c}\text { Molar } \\
\text { conductance } \\
\left(\Omega^{-1} \mathrm{~cm}^{-1} \mathrm{~mol}^{-1}\right)\end{array}$ & $\begin{array}{c}\text { Magnetic } \\
\text { values } \\
(298 \mathrm{~K})\end{array}$ & $\begin{array}{l}\text { Bands observed } \\
\quad \lambda_{\max }(\mathrm{nm})\end{array}$ & $\begin{array}{l}m / z \text { ratio } \\
\text { Obs. (Calcd.) }\end{array}$ \\
\hline MB-1. & $\begin{array}{l}\text { Bis(o-methylpyridine) salicylatooxovanadium } \\
{\left[\mathrm{VO}\left(\mathrm{C}_{7} \mathrm{H}_{4} \mathrm{O}_{3}\right)\left(\mathrm{C}_{6} \mathrm{H}_{7} \mathrm{~N}\right)_{2}\right]}\end{array}$ & 9 & 1.73 & $\begin{array}{l}273.13,326.86 \\
\quad 420.09\end{array}$ & $388.811(388.942)$ \\
\hline MB-2. & $\begin{array}{l}\text { Bis(m-methylpyridine)sulphosalicylatooxovanadium } \\
{\left[\mathrm{VO}\left(\mathrm{C}_{7} \mathrm{H}_{5} \mathrm{O}_{6} \mathrm{~S}\right)\left(\mathrm{C}_{6} \mathrm{H}_{7} \mathrm{~N}\right)_{2}\right]}\end{array}$ & 3 & 1.77 & $\begin{array}{l}272.13,327.01 \\
\quad 420.01\end{array}$ & 468.009 (469.008) \\
\hline MB-3. & $\begin{array}{l}\text { Bis(o-aminopyridine) sulphosalicylatooxovanadium } \\
{\left[\mathrm{VO}\left(\mathrm{C}_{7} \mathrm{H}_{5} \mathrm{O}_{6} \mathrm{~S}\right)\left(\mathrm{C}_{5} \mathrm{H}_{6} \mathrm{~N}_{2}\right)_{2}\right]}\end{array}$ & 4 & 1.74 & $\begin{array}{l}274.12,327.94 \\
\quad 420.21\end{array}$ & $471.123(471.008)$ \\
\hline MB-4. & $\begin{array}{l}\text { (1,10-Phenanthroline) sulphosalicylatooxovanadium } \\
{\left[\mathrm{VO}\left(\mathrm{C}_{7} \mathrm{H}_{5} \mathrm{O}_{6} \mathrm{~S}\right)\left(\mathrm{C}_{12} \mathrm{H}_{8} \mathrm{~N}_{2}\right)\right]}\end{array}$ & 7 & 1.73 & $\begin{array}{l}274.05,327.32 \\
\quad 422.12\end{array}$ & $462.999(463.008)$ \\
\hline MB-5. & $\begin{array}{l}\text { (Ethylenediamine) sulphosalicylatooxovanadium }^{(\mathrm{IV})} \\
{\left[\mathrm{VO}\left(\mathrm{C}_{7} \mathrm{H}_{5} \mathrm{O}_{6} \mathrm{~S}\right)\left(\mathrm{C}_{2} \mathrm{H}_{8} \mathrm{~N}_{2}\right)\right]}\end{array}$ & 7 & 1.73 & $\begin{array}{l}274.21,326.82 \\
\quad 412.32\end{array}$ & $439.000(439.008)$ \\
\hline
\end{tabular}

TABLE 2: Main infrared absorption frequencies $\left(\mathrm{cm}^{-1}\right)$ corresponding to various groups in the VO(SA/SSA) complexes with nitrogen donors.

\begin{tabular}{|c|c|c|c|c|c|c|c|c|c|}
\hline Codes & Name of the complex & $v_{\mathrm{C}-\mathrm{O}}$ & $v_{\mathrm{C}=\mathrm{O}}$ & $v_{\mathrm{C}=\mathrm{N}}$ & $v_{\mathrm{C}=\mathrm{C}}$ & $v_{\mathrm{V}-\mathrm{N}}$ & $v_{\mathrm{V}-\mathrm{O}}$ & $\begin{array}{l}v_{\mathrm{S}=\mathrm{O}} \\
\text { sym., asym }\end{array}$ & $v_{\mathrm{V}=\mathrm{O}}$ \\
\hline MB-1. & $\begin{array}{l}\text { Bis(o-methylpyridine) salicylatooxovanadium }{ }^{(I V)} \\
{\left[\mathrm{VO}\left(\mathrm{C}_{7} \mathrm{H}_{4} \mathrm{O}_{3}\right)\left(\mathrm{C}_{6} \mathrm{H}_{7} \mathrm{~N}\right)_{2}\right]}\end{array}$ & 1392.3 & 1662.4 & 1606.5 & 1583.3 & 467.3 & 540.2 & - & 950.3 \\
\hline MB-2. & $\begin{array}{l}\text { Bis(m-methylpyridine }) \text { sulphosalicylatooxovanadium } \\
{\left[\mathrm{VO}\left(\mathrm{C}_{7} \mathrm{H}_{4} \mathrm{O}_{6} \mathrm{~S}\right)\left(\mathrm{C}_{6} \mathrm{H}_{7} \mathrm{~N}\right)_{2}\right]}\end{array}$ & 1395.6 & 1663.8 & 1625.0 & 1562.7 & 450.1 & 551.2 & $\begin{array}{c}1131.2 \\
1325.4\end{array}$ & 954.8 \\
\hline MB-3. & $\begin{array}{l}\text { Bis(o-aminopyridine)sulphosalicylatooxovanadium } \\
{\left[\mathrm{VO}\left(\mathrm{C}_{7} \mathrm{H}_{4} \mathrm{O}_{6} \mathrm{~S}\right)\left(\mathrm{C}_{5} \mathrm{H}_{6} \mathrm{~N}_{2}\right)_{2}\right]}\end{array}$ & 1390.5 & 1680.2 & 1605.0 & 1558.8 & 470.2 & 679.2 & $\begin{array}{l}1128.6 \\
1317.9\end{array}$ & 915.5 \\
\hline MB-4. & $\begin{array}{l}\text { (1,10-Phenanthroline)sulphosalicylatooxovanadium } \\
{\left[\mathrm{VO}\left(\mathrm{C}_{7} \mathrm{H}_{4} \mathrm{O}_{6} \mathrm{~S}\right)\left(\mathrm{C}_{12} \mathrm{H}_{8} \mathrm{~N}_{2}\right)\right]}\end{array}$ & 1396.3 & 1686.0 & 1602.7 & 1560.0 & 453.3 & 532.3 & $\begin{array}{l}1126.3 \\
1333.1\end{array}$ & 945.9 \\
\hline MB-5. & $\begin{array}{l}\text { (Ethylenediamine) sulphosalicylatooxovanadium }^{(\mathrm{IV})} \\
{\left[\mathrm{VO}\left(\mathrm{C}_{7} \mathrm{H}_{4} \mathrm{O}_{6} \mathrm{~S}\right)\left(\mathrm{C}_{2} \mathrm{H}_{8} \mathrm{~N}_{2}\right)\right]}\end{array}$ & 1380.2 & 1680.1 & 1601.9 & 1570.6 & 470.0 & 676.0 & $\begin{array}{l}1124.0 \\
1316.1\end{array}$ & 947.6 \\
\hline
\end{tabular}

meso-aryl protons; ${ }^{13} \mathrm{C} \mathrm{NMR}\left(\mathrm{CDCl}_{3}\right): 123.5\left(\mathrm{C}_{\text {meso }}\right), 128.4$ $\left(\mathrm{C}_{\mathrm{m}, \mathrm{m}^{\prime}}\right), 128.8\left(\mathrm{C}_{\mathrm{p}}\right), 131.5\left(\mathrm{C}_{\beta}\right), 135.0\left(\mathrm{C}_{\mathrm{o}, \mathrm{o}^{\prime}}\right), 142.6\left(\mathrm{C}_{\mathrm{p}^{\prime}}\right) \mathrm{ppm}$ and $(145.0 \mathrm{ppm})$ for $\mathrm{C}_{\alpha}$ carbons; anal. calcd. for $\mathrm{C}_{44} \mathrm{H}_{30} \mathrm{~N}_{4}$ (614.75): C, 76.05; H, 4.42; N, 10.86; found: C, 76.02; H, 4.40; $\mathrm{N}, 10.82 \%$.

\section{Biological Evaluation}

5.1. Antifungal Studies. In vitro antifungal activity of some of the selected complexes was tested against the pathogen "Sclerotium rolfsii" by the poisoned food method using Potato Dextrose Agar (PDA) nutrient as the medium [14]. The linear growth of fungus in control and treatment were recorded at different concentrations of the complexes. The media was prepared by dissolving dextrose and agar to the solution of fresh potato starch. The sterilization of media (PDA) was carried out by autoclaving it at $15 \mathrm{~mm}$ pressure per square inch for 20 minutes in sterile conditions. The test solutions were prepared by dissolving the compounds in DMSO. The test solutions were mixed in the PDA and poured into Petri plates in sterilized conditions inside laminar flow. After solidification, the plates were inoculated with seven-day-old culture of pathogen by placing $2 \mathrm{~mm}$ bit in the centre of plates. The inoculated plates were incubated at $27^{\circ} \mathrm{C}$ for 4 days. The linear growth of fungus in control and treatment were recorded at different concentrations of the complexes.
The growth inhibition of "Sclerotium rolfsii" over control was calculated as

$$
\% \text { Inhibition }(I)=\frac{C-T}{C} \times 100 \text {, }
$$

where $I=$ percent inhibition, $C=$ mean growth of fungus in ( $\mathrm{mm}$ ) in control, and $T=$ mean growth of fungus in $(\mathrm{mm})$ in treatment.

5.2. Antibacterial Studies. Qualitative analysis for screening of antimicrobial activity of the complexes was carried out by agar-well-diffusion method [15] with modifications. The complexes were tested against two Gram positive bacteria (Bacillus subtilis MTCC2389, Staphylococcus aureus MTCC7443) and three Gram negative bacteria (Micrococcus luteus MTCC4821, Escherichia coli MTCC2127, and Pseudomonas fluorescens MTCC4828). $20 \mathrm{~mL}$ of sterilized nutrient agar was inoculated with $100 \mathrm{~mL}$ of bacterial suspension $\left(10^{8} \mathrm{CFU} / \mathrm{mL}\right)$ and then poured onto sterilized Petri plate. The agar plate was left to solidify at room temperature. A well of $6 \mathrm{~mm}$ was aseptically bored into the agar plate. Then, $20 \mathrm{~mL}$ of the complexes (diluted with DMSO, 1:1) was added in each well. Chloramphenicol $(10 \mu \mathrm{g})$ was used as a positive reference to determine the sensitivity of bacteria. The plates were kept at $4^{\circ} \mathrm{C}$ for 2 hours to allow the dispersal and then incubated at $37^{\circ} \mathrm{C}$ for 24 hours. 
TABLE 3: ${ }^{13} \mathrm{C}$ NMR data showing chemical shift (in ppm) values of the VO(SA/SSA) complexes with nitrogen donors.

\begin{tabular}{|c|c|c|c|}
\hline Codes & Name of the complex & Salicylate/sulphosalicylate carbons & Ligand carbons \\
\hline MB-1. & $\begin{array}{l}\text { Bis(o-methylpyridine) salicylatooxovanadium } \\
{\left[\mathrm{VO}\left(\mathrm{C}_{7} \mathrm{H}_{4} \mathrm{O}_{3}\right)\left(\mathrm{C}_{6} \mathrm{H}_{7} \mathrm{~N}\right)_{2}\right]}\end{array}$ & $\begin{array}{c}119.5\left(\mathrm{C}_{1}\right), 165.8\left(\mathrm{C}_{2}\right), 116.5\left(\mathrm{C}_{3}\right), \\
133.3\left(\mathrm{C}_{4}\right), 120.1\left(\mathrm{C}_{5}\right), 132.6\left(\mathrm{C}_{6}\right) \\
173.2\left(\mathrm{C}_{7}\right)\end{array}$ & $\begin{array}{l}151.1\left(\mathrm{C}_{1}\right), 133.8\left(\mathrm{C}_{2}\right), 134.4\left(\mathrm{C}_{3}\right) \\
123.0\left(\mathrm{C}_{4}\right) 147.5\left(\mathrm{C}_{5}\right), 24.3\left(\mathrm{CH}_{3}\right)\end{array}$ \\
\hline MB-2. & $\begin{array}{l}\text { Bis(m-methylpyridine)sulphosalicylatooxovanadium } \\
\text { (IV) } \\
{\left[\mathrm{VO}\left(\mathrm{C}_{7} \mathrm{H}_{4} \mathrm{O}_{6} \mathrm{~S}\right)\left(\mathrm{C}_{6} \mathrm{H}_{7} \mathrm{~N}\right)_{2}\right]}\end{array}$ & $\begin{aligned} 120.5\left(\mathrm{C}_{1}\right), & 163.5\left(\mathrm{C}_{2}\right), 117.6\left(\mathrm{C}_{3}\right) \\
134.2\left(\mathrm{C}_{4}\right), & 122.4\left(\mathrm{C}_{5}\right), 131.0\left(\mathrm{C}_{6}\right) \\
& 172.0\left(\mathrm{C}_{7}\right)\end{aligned}$ & $\begin{array}{l}158.6\left(\mathrm{C}_{1}\right), 124.1\left(\mathrm{C}_{2}\right), 136.4\left(\mathrm{C}_{3}\right) \\
123.3\left(\mathrm{C}_{4}\right) 147.5\left(\mathrm{C}_{5}\right), 22.3\left(\mathrm{CH}_{3}\right)\end{array}$ \\
\hline MB-3. & $\begin{array}{l}\text { Bis(o-aminopyridine) sulphosalicylatooxovanadium } \\
{\left[\mathrm{VO}\left(\mathrm{C}_{7} \mathrm{H}_{4} \mathrm{O}_{6} \mathrm{~S}\right)\left(\mathrm{C}_{5} \mathrm{H}_{6} \mathrm{~N}_{2}\right)_{2}\right]}\end{array}$ & $\begin{array}{c}\text { 119.2 }\left(\mathrm{C}_{1}\right), 166.4\left(\mathrm{C}_{2}\right), 116.3\left(\mathrm{C}_{3}\right) \\
\text { 135.1 }\left(\mathrm{C}_{4}\right), 121.0\left(\mathrm{C}_{5}\right), 133.3\left(\mathrm{C}_{6}\right) \\
174.4\left(\mathrm{C}_{7}\right)\end{array}$ & $\begin{array}{l}159.3\left(\mathrm{C}_{1}\right), 120.1\left(\mathrm{C}_{2}\right), 130.4\left(\mathrm{C}_{3}\right) \\
121.3\left(\mathrm{C}_{4}\right) 142.5\left(\mathrm{C}_{5}\right)\end{array}$ \\
\hline MB-4. & $\begin{array}{l}\text { (1,10-Phenanthroline) sulphosalicylatooxovanadium } \\
{\left[\mathrm{VO}\left(\mathrm{C}_{7} \mathrm{H}_{4} \mathrm{O}_{6} \mathrm{~S}\right)\left(\mathrm{C}_{12} \mathrm{H}_{8} \mathrm{~N}_{2}\right)\right]}\end{array}$ & $\begin{array}{c}\text { 118.9 }\left(\mathrm{C}_{1}\right), 165.8\left(\mathrm{C}_{2}\right), 116.5\left(\mathrm{C}_{3}\right) \\
133.3\left(\mathrm{C}_{4}\right), 122.2\left(\mathrm{C}_{5}\right), 132.4\left(\mathrm{C}_{6}\right) \\
172.3\left(\mathrm{C}_{7}\right)\end{array}$ & $\begin{array}{c}153.5\left(\mathrm{C}_{2}\right), 146.1\left(\mathrm{C}_{9}\right), 143.5\left(\mathrm{C}_{4}\right), \\
140.5\left(\mathrm{C}_{6 \mathrm{~b}}\right), 140.0\left(\mathrm{C}_{4 \mathrm{~b}}\right), 136.7\left(\mathrm{C}_{7}\right), \\
129.0\left(\mathrm{C}_{6 \mathrm{a}}\right), 128.1\left(\mathrm{C}_{4 \mathrm{a}}\right), 126.3\left(\mathrm{C}_{6}\right), \\
125.3\left(\mathrm{C}_{5}\right), 124.3\left(\mathrm{C}_{8}\right), 124.0\left(\mathrm{C}_{3}\right)\end{array}$ \\
\hline MB-5. & $\begin{array}{l}\text { (Ethylenediamine)sulphosalicylatooxovanadium } \\
{\left[\mathrm{VO}\left(\mathrm{C}_{7} \mathrm{H}_{4} \mathrm{O}_{6} \mathrm{~S}\right)\left(\mathrm{C}_{2} \mathrm{H}_{8} \mathrm{~N}_{2}\right)\right]}\end{array}$ & $\begin{aligned} 119.3\left(\mathrm{C}_{1}\right), & 165.8\left(\mathrm{C}_{2}\right), 116.5\left(\mathrm{C}_{3}\right) \\
133.3\left(\mathrm{C}_{4}\right), & 122.1\left(\mathrm{C}_{5}\right), 133.2\left(\mathrm{C}_{6}\right) \\
& 173.0\left(\mathrm{C}_{7}\right)\end{aligned}$ & $34\left(\mathrm{C}_{1} \& \mathrm{C}_{2}\right)$ \\
\hline
\end{tabular}

TABLE 4: In vitro evaluation of oxovanadium(IV) macrocyclic complexes against Sclerotium rolfsii.

\begin{tabular}{|c|c|c|c|c|}
\hline Codes & Complex & $\begin{array}{c}\text { Concentration } \\
(\mathrm{ppm})\end{array}$ & $\begin{array}{l}\text { Colony diameter } \\
(\mathrm{mm})\end{array}$ & $\begin{array}{c}\% \text { inhibition } \\
I=[(C-T) / C] \times 100\end{array}$ \\
\hline \multirow{3}{*}{ MB-1. } & \multirow{3}{*}[\mathrm{VO}(\mathrm{SSA})(\mathrm{o}-\mathrm{MePy})_{2}]{} & 100 & 35 & 61.11 \\
\hline & & 200 & 11 & 87.77 \\
\hline & & 300 & 7 & 92.22 \\
\hline \multirow{3}{*}{ MB-2. } & \multirow{3}{*}[\mathrm{VO}(\mathrm{SA})(\mathrm{m}-\mathrm{MePy})_{2}]{} & 100 & 35 & 61.11 \\
\hline & & 200 & 33 & 63.33 \\
\hline & & 300 & 7 & 92.22 \\
\hline \multirow{3}{*}{ MB-3. } & \multirow{3}{*}[\mathrm{VO}(\mathrm{SSA})(\mathrm{o}-\mathrm{AmPy})_{2}]{} & 100 & 33 & 63.33 \\
\hline & & 200 & 30 & 66.66 \\
\hline & & 300 & 8 & 91.11 \\
\hline \multirow{3}{*}{ MB-4. } & \multirow{3}{*}{ [VO(SSA)(1,10-Phen)] } & 100 & 37 & 58.8 \\
\hline & & 200 & 20 & 77.7 \\
\hline & & 300 & 5 & 94.4 \\
\hline \multirow{3}{*}{ MB-5. } & \multirow{3}{*}[\mathrm{VO}(\mathrm{SSA})(\mathrm{en})]{} & 100 & 40 & 55.5 \\
\hline & & 200 & 22 & 75.5 \\
\hline & & 300 & 8 & 91.1 \\
\hline \multirow{3}{*}{ MB-6. } & \multirow{3}{*}[\mathrm{VO}(\mathrm{tpp})(\mathrm{o}-\mathrm{AmPy})]{} & 100 & 60 & 33.34 \\
\hline & & 200 & 55 & 38.9 \\
\hline & & 300 & 53 & 41.2 \\
\hline
\end{tabular}

Mean Colony diameter of control $C=90 \mathrm{~mm}$.

\subsection{In Vitro Cytotoxicity against Human Cancer Cell Lines}

5.3.1. Cell Lines and Cell Cultures. The human cancer cell lines were obtained either from the National Center for Cell Science, Pune, India, or the National Cancer Institute, Frederick, MD, USA. The human prostrate (PC-3), lung (A-549), and acute lymphoblastic leukemia (THP-1) cell line were grown and maintained in RPMI-1640 medium, $\mathrm{pH}$ 7.4, whereas DMEM was used for Breast (MCF-7). The media were supplemented with FCS (10\%), penicillin (100 units/mL), streptomycin $(100 \mu \mathrm{g} / \mathrm{mL})$, and glutamine
( $2 \mathrm{mM}$ ) and cells were grown in $\mathrm{CO}_{2}$ incubator (Heraeus, $\mathrm{GmbH}$, Germany) at $37^{\circ} \mathrm{C}$ with $90 \%$ humidity and $5 \% \mathrm{CO}_{2}$. Cells were treated with samples dissolved in DMSO while the untreated control cultures received only the vehicle (DMSO, $<0.2 \%)$.

5.3.2. Cytotoxicity Assay. In vitro cytotoxicity against human cancer cell lines was determined using sulphorhodamine B dye assay $[16,17]$. Both test samples stock solutions were prepared in DMSO and serially diluted with growth medium to obtain the desired concentrations. 


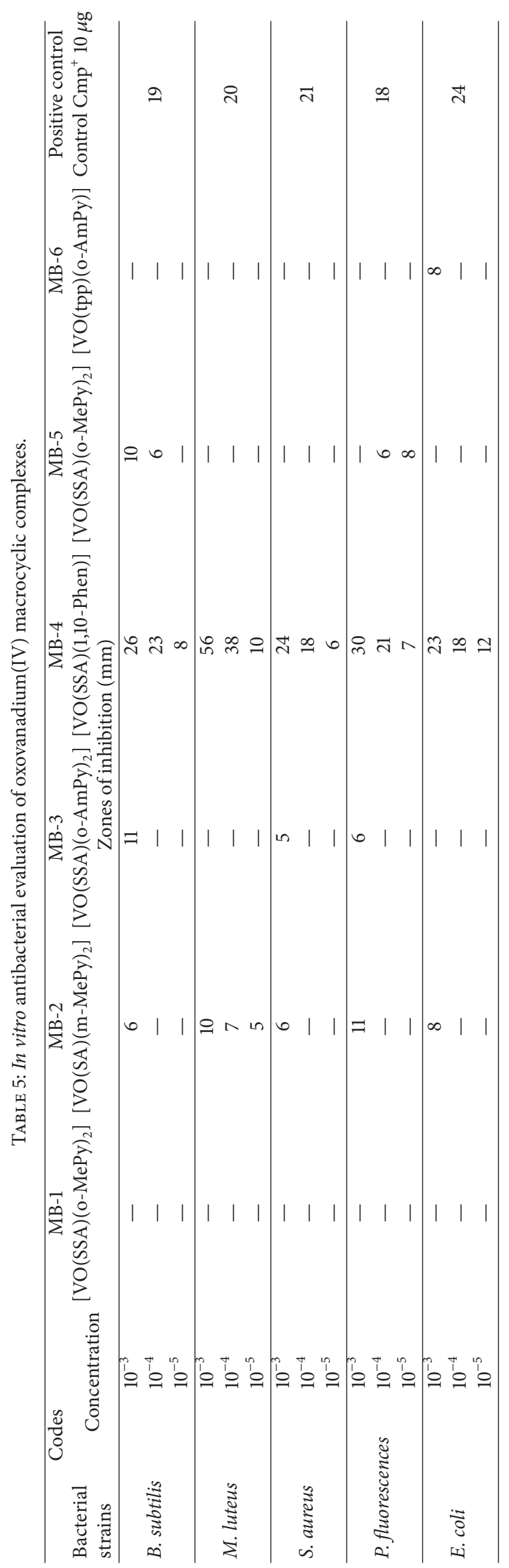




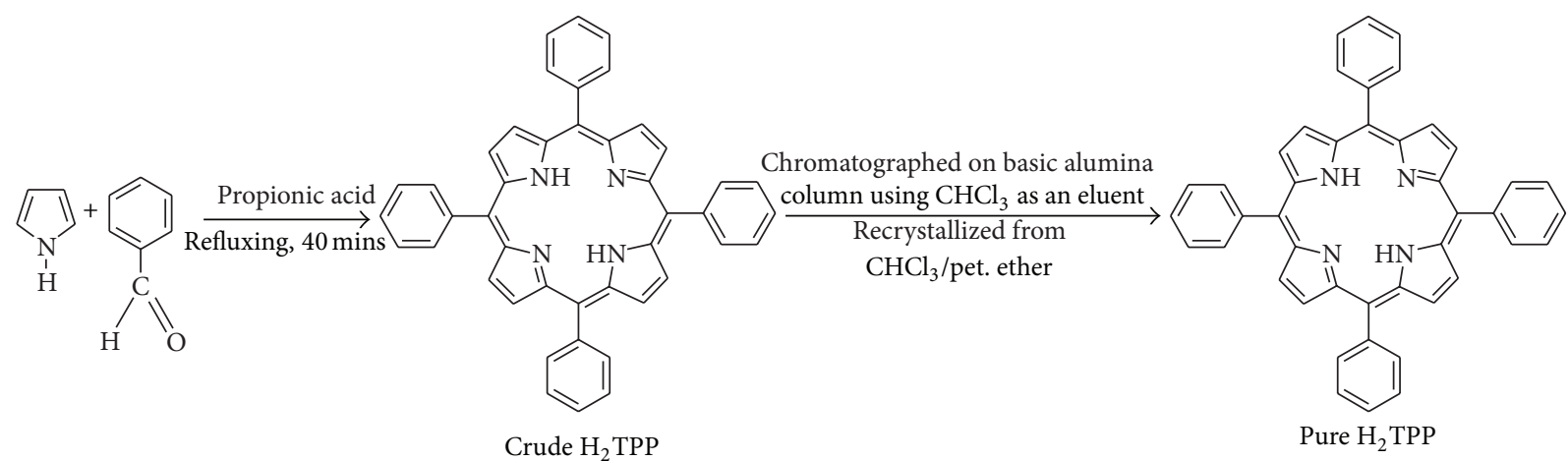

SCHEME 1: Synthetic route for the synthesis of meso-tetraphenylporphyrin.

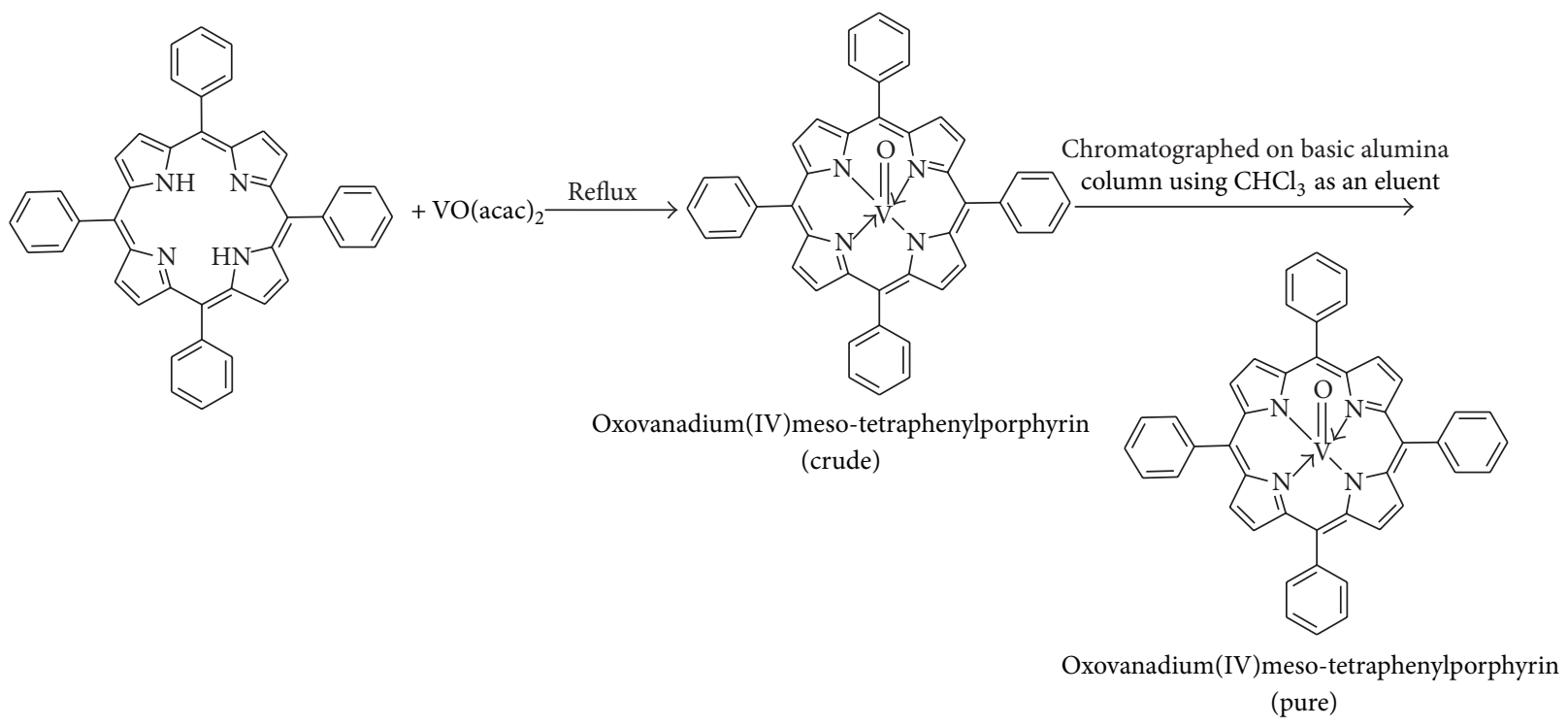

Scheme 2: Synthetic route for the synthesis of oxovanadium(IV) meso-tetraphenylporphyrin.

\section{Results and Discussion}

The analytical and spectroscopic results showed that the complexes of $[\mathrm{VO}(\mathrm{SA} / \mathrm{SSA})]$ with unidentate nitrogen donors have general formula $\left[\mathrm{VO}(\mathrm{SA})(\mathrm{L})_{2}\right] /\left[\mathrm{VO}(\mathrm{SSA})(\mathrm{L})_{2}\right]$ where $\mathrm{L}=$ substituted pyridines and with bidentate nitrogen donors the general formula is $[\mathrm{VO}(\mathrm{SA})(\mathrm{L}-\mathrm{L})] /[\mathrm{VO}(\mathrm{SSA})(\mathrm{L}-$ $\mathrm{L})$ ] where $\left(\mathrm{L}-\mathrm{L}=\right.$ ethylene diamine, $2,2^{\prime}$-bipyridyl and 1,10 phenanthroline). The general formula for [VO(tpp)] complexes is $[\mathrm{VO}(\mathrm{tpp})(\mathrm{L})]$ (where $\mathrm{L}=$ substituted pyridines).

6.1. Conductance and Magnetic Measurements. The [VO(SA/ SSA)(L/L-L)] complexes in DMSO have shown the molar conductance values in the range of $2-9 \Omega^{-1} \mathrm{~cm}^{2} \mathrm{~mol}^{-1}$ revealing their neutral character and they exhibit magnetic moments in the range 1.73-1.79 B.M. which is in accordance with the square pyramidal geometry around the metal atom in the complex and also the monomeric nature of these complexes (Table 1) [18].

6.2. Electronic Spectra. The electronic spectrum in the visible region of the complexes attributed to $\mathrm{d}-\mathrm{d}$ transitions is altered in intensity and shifts in position of the absorption bands relative to the corresponding oxovanadium(IV) ions due to which all these complexes exhibit only one absorption band in the range of $410-430 \mathrm{~nm}$ corresponding to $\mathrm{d}-\mathrm{d}$ transition.

The characteristic absorption peak of the salicylic acid and sulfosalicylic acid occurs at 298 and $295 \mathrm{~nm}$ while in the complex this peak exhibits bathochromic (red) shift to 326 and $327 \mathrm{~nm}$, respectively. The absorption maxima of the free phenanthroline and in the complexed form appears in the ultraviolet region at 229 and $263 \mathrm{~nm}$, which are assigned to the $\pi-\pi^{*}$ transitions of the aromatic ring, belonging to the $\mathrm{K}$ band and for free $2,2^{\prime}$-bipyridine and in the complex, the absorption maxima appear in the ultraviolet region at 204 and $239 \mathrm{~nm}$. The bands due to these ligands exhibit red shift on complexation [19]. The complexes with different nitrogen donors are red shifted. The electronic spectra of the complexes were also recorded in different concentrations of DMSO and these spectra show that absorbance goes on increasing with the increase in concentration of the solution. These spectra were quite similar to one another and were interpreted on the basis of a 4-coordinate square-pyramidal 


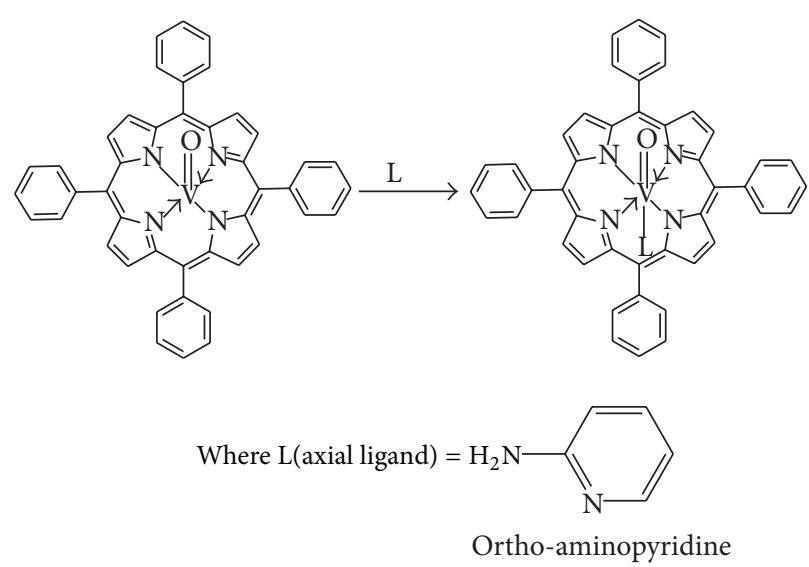

Scheme 3: Synthetic route for the synthesis of axially ligated VO(IV)porphyrin.

geometry around vanadium metal. The spectra gave $\lambda_{\max }$ values as shown in Table 1.

The data for axially ligated [VO(tpp)L] is given in the synthesis section. It was observed from the data that the Qband and B-band of six coordinated [VO(tpp)L] complexes are red shifted (bathochromic shifts) with different pyridines (nitrogen ligands) due to the basic nature of pyridines. The nonbonding electron present on heteroatom nitrogen can be easily donated and hence it requires less energy for transition and therefore shows bathochromic shifts. There is also a formation of new band around $610 \mathrm{~nm}$ in axially ligated [VO(tpp)]L] complex showing their octahedral geometry around the metal ion.

6.3. IR Spectra. The IR spectra of the complexes containing substituted pyridines as ligands show bands in the range of $1640-1602 \mathrm{~cm}^{-1}$ which are attributed to $v_{(\mathrm{C}=\mathrm{N})}$ vibrations. The band is shifted to lower frequency region in all the complexes indicating that the bond formation is taking place through the nitrogen of pyridine ring $[20,21]$. The $v_{(\mathrm{C}-\mathrm{O})}$ phenolic stretching frequencies of the salicylate ligand are observed in the region $1259-1228 \mathrm{~cm}^{-1}$ for the free ligands which gets shifted to higher region $1395-1350 \mathrm{~cm}^{-1}$ in the complexes. It is indicative of the bonding through the phenolic oxygen of the salicylic acid. The $v_{(\mathrm{COO})}$ band of salicylic acid appears in the range of $1631-1620 \mathrm{~cm}^{-1}$ which indicates the involvement of carboxylate oxygen in the complex formation. It also proves the bidentate chelating nature of the salicylate ion. The $\mathrm{SO}_{3} \mathrm{H}$ group of the 5-SSA shows bands for $v_{(\mathrm{S}=\mathrm{O})}$ asymmetric and $v_{(\mathrm{S}=\mathrm{O})}$ symmetric vibrations at $1350 \mathrm{~cm}^{-1}$ and $1150 \mathrm{~cm}^{-1}$. Both these bands are lowered in frequency in the complexes.

The bands appearing in the $681-673 \mathrm{~cm}^{-1}$ range correspond to $v_{(\mathrm{V}-\mathrm{O})}$ and bands about $470 \mathrm{~cm}^{-1}$ correspond to $v_{(\mathrm{V}-\mathrm{N})}$, respectively. The characteristic band at $950 \pm 35 \mathrm{~cm}^{-1}$ of the complexes is that of $v_{(\mathrm{V}=\mathrm{O})}[21]$.

The spectrum of $[\mathrm{VO}(\mathrm{tpp})]$ shows shift in values of absorption peaks as compared to their corresponding freebase porphyrins. In $[\mathrm{VO}(\mathrm{tpp})]$, aromatic $v_{(\mathrm{C}-\mathrm{H})}$ occurs at $2961 \mathrm{~cm}^{-1}, v_{(\mathrm{C}-\mathrm{N})}$ at $1088 \mathrm{~cm}^{-1}, v_{(\mathrm{C}=\mathrm{N})}$ at $1348 \mathrm{~cm}^{-1}[22$, $23]$, and $v_{(\mathrm{C}=\mathrm{C})}$ at $1634 \mathrm{~cm}^{-1}$. There is the disappearance of
$\mathrm{N}-\mathrm{H}$ band stretch and appearance of an additional $\mathrm{V}=\mathrm{O}$ stretching vibration in the frequency range between 900 and $1030 \mathrm{~cm}^{-1}$, which confirms the presence of vanadium metal in porphyrin, the value of vibrational frequencies of axially ligated $[\mathrm{VO}(\mathrm{tpp})]$ is shown in Table 2. After the incorporation of pyridine ligand in $[\mathrm{VO}(\mathrm{tpp})]$ complexes, the $\mathrm{V}=\mathrm{O}$ band gets displayed to lower frequencies in comparison to [VO(tpp)] complexes. For example, for $\left[\mathrm{VO}(\mathrm{tpp})\left(\mathrm{o}-\mathrm{NH}_{2} \mathrm{Py}\right)\right]$ porphyrins, there is additional stretching vibration due to presence of $\mathrm{NH}_{2}$ group which lies at $3274 \mathrm{~cm}^{-1}$ for $\mathrm{NH}_{2}$ symmetric and $3362 \mathrm{~cm}^{-1}$ for $\mathrm{NH}_{2}$ asymmetric stretching frequencies in addition to vibration for aromatic $v_{(\mathrm{C}=\mathrm{C})}$ at $1652 \mathrm{~cm}^{-1}, v_{(\mathrm{C}-\mathrm{N})}$ at $1094 \mathrm{~cm}^{-1}, v_{(\mathrm{C}=\mathrm{N})}$ at $1344 \mathrm{~cm}^{-1}, v_{(\mathrm{V}=\mathrm{O})}$ at $1010 \mathrm{~cm}^{-1}, \mathrm{NH}_{2}$ symmetric stretching at $3280 \mathrm{~cm}^{-1}$, and asymmetric stretching at $3450 \mathrm{~cm}^{-1}$, respectively. The other vibrational frequencies that are not assigned in Table 2 are attributed to vibration of porphyrin and pyridine rings.

6.4. ${ }^{1}$ H NMR Spectra. The ${ }^{1} \mathrm{H}$ NMR spectra show four signals for the salicylate protons in the region below $6.0 \mathrm{ppm}$ which are merged into each other. The chemical shift values for pyridine protons were observed in the region below $7.2 \mathrm{ppm}$ as a multiplet with their usual splitting pattern. The chemical shift for the aryl protons of the bipyridyl moiety appeared in the region $8.0-8.6 \mathrm{ppm}$. The complexes containing $1,10-$ phenanthroline show the characteristic resonances for the phenyl protons of 1,10-phenanthroline in the region 7.8$9.0 \mathrm{ppm}$. All these signals had been found to merge with the signals of salicylate protons. The protons for the $-\mathrm{CH}_{3}$ and $-\mathrm{NH}_{2}$ groups occur at 3.2-3.4 and $3.8 \mathrm{ppm}$, respectively. The protons of the pyridine ring attached to the central metal are merged with the protons of the salicylate ring.

The ${ }^{1} \mathrm{H}$ NMR spectra of axially ligated [VO(tpp)L] are highly characteristic and provide structural information of these compounds in solution. The presence of $\mathrm{VO}(\mathrm{IV})$ metal ion in porphyrin ring results in the shift of resonances towards low-field (at higher frequency) accompanied by marginal changes in the ${ }^{1} \mathrm{H}$ NMR spectra. All the freebase porphyrin reveals characteristic resonances of imino protons, while metallated derivatives show the absence of 

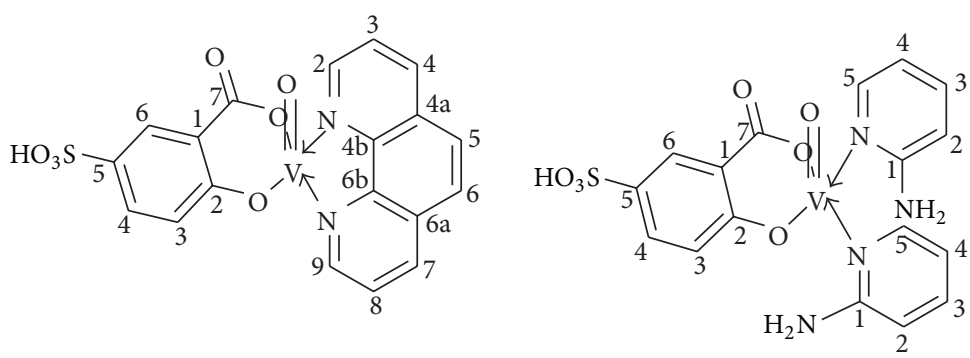

FIGURE 1: Figure showing labelled carbon atoms.

imino signals. The $\beta$-pyrrole protons of [ $\mathrm{VO}(\mathrm{tpp}) \mathrm{L}]$ resonate as a singlet at $9.8 \mathrm{ppm}$ which are downfield relative to $\mathrm{H}_{2} \mathrm{tpp}$ (where these are found at $8.6 \mathrm{ppm}$ ) and meso-aryl protons resonate as doublet at $8.4 \mathrm{ppm}$ of ortho- and $7.9 \mathrm{ppm}$ of metaprotons which are also deshielded as compared to $\mathrm{H}_{2}$ tpp (where these are found at $8.17 \mathrm{ppm}$ ) due to the presence of electron releasing oxo-group. The ${ }^{1} \mathrm{H}$ NMR and ${ }^{13} \mathrm{C} N M R$ spectral data of axially ligated $[\mathrm{VO}(\mathrm{tpp})(\mathrm{o}-\mathrm{AmPy})]$ is given in experimental section.

The ${ }^{13} \mathrm{C}$ NMR spectral data of the complexes along with the possible assignments were recorded in $\mathrm{DMSO}_{-} \mathrm{d}_{6}$ (of vanadium salicylate complexes) and $\mathrm{CDCl}_{3}$ (of $\mathrm{VO}(\mathrm{tpp})$ ) and reported in Section 2. All the carbons were found in the expected region and the present studies are well supported by their IR and ${ }^{1} \mathrm{H}$ NMR spectral data. The salicylate carbons $\left(\mathrm{C}_{1}\right.$ and $\left.\mathrm{C}_{6}\right)$ appeared in the region at $119-133 \mathrm{ppm}$ and $\mathrm{C}_{7}$ appeared around $173 \mathrm{ppm}$. Similarly, the carbons $\left(\mathrm{C}_{1}-\right.$ $\mathrm{C}_{5}$ and $\mathrm{C}_{1}-\mathrm{C}_{5}$ ) of all the pyridine ligands were found in the region at $123-151 \mathrm{ppm}$. In addition, methyl methylene carbons were observed at 23-24 and 34 ppm, respectively. The 1,10-phenanthroline carbons are found in the range of 124$153 \mathrm{ppm}$. Furthermore, the expected values of carbon atoms agreed well with the number of carbons in the proposed structures (Table 3). The labelled carbon atoms have also been shown in Figure 1.

${ }^{51} \mathrm{~V}$ NMR of complexes were also performed and found to be NMR silent in +4 oxidation state.

6.5. Mass Spectral Studies. The mass spectra of these complexes show molecular ion peaks which are in good agreement with the structure suggested by elemental analysis and spectral and magnetic studies. For example, for molecular ions $\left[\mathrm{VO}(\mathrm{SSA})(\mathrm{o}-\mathrm{MePy})_{2}\right]^{+}, \quad[\mathrm{VO}(\mathrm{SA})(\mathrm{m}-$ $\left.\mathrm{MePy}_{2}\right]^{+},\left[\mathrm{VO}(\mathrm{SSA})(\mathrm{o}-\mathrm{AmPy})_{2}\right]^{+},[\mathrm{VO}(\mathrm{SSA})(1,10-\mathrm{Phen})]^{+}$, $\left[\mathrm{VO}(\mathrm{tpp})(\mathrm{o}-\mathrm{AmPy})_{2}\right]^{+}$, and $[\mathrm{VO}(\mathrm{tpp})(\mathrm{o}-\mathrm{AmPy})] \mathrm{m} / z$ values are observed at 388.811, 468.543, 471.123, 462.999, 439.000, and 774.9 , respectively (Table 1 ).

6.6. Thermogravimetric Analysis. Thermogravimetric analysis of two representative samples was carried out in an air atmosphere at a heating rate of $10^{\circ} \mathrm{C} / \mathrm{min}$ to examine thermal stability of the compound. The TG curve of the complex $\left[\mathrm{VO}(\mathrm{SSA})\left(\mathrm{o}-\mathrm{NH}_{2} \mathrm{Py}\right)_{2}\right]$ shows a continuous weight loss starting from 200 to $600^{\circ} \mathrm{C}$, when a stable $\mathrm{V}_{2} \mathrm{O}_{5}$ is formed at $513.7^{\circ} \mathrm{C}$. The curve shows an initial weight loss of a $-\mathrm{SO}_{3} \mathrm{H}$ group at $233.4^{\circ} \mathrm{C}$, (Obs. wt. loss $=17.9 \%$, Calc. wt. loss $=$ $17.24 \%)$. This is followed by a loss of $-\mathrm{C}_{7} \mathrm{H}_{3} \mathrm{O}_{3}$ group at $377.1^{\circ} \mathrm{C}$ (Obs. wt. loss 30.2\%, Calc. wt. loss $=28.93 \%$ ). At $395.1^{\circ} \mathrm{C}$, the loss of two molecules of $-\mathrm{N}_{2} \mathrm{C}_{5} \mathrm{H}_{6}$ (Obs. wt. loss $40.1 \%$, Calc. wt. loss $=39.9 \%$ ) had been observed and finally stable $\mathrm{V}_{2} \mathrm{O}_{5}$ oxide of vanadium is formed. There are some exothermal peaks observed in the range of $380-480^{\circ} \mathrm{C}$ showing major weight loss in this region.

The thermal stability curve of the complex [VO(tpp) $\left.\left(\mathrm{N}_{2} \mathrm{C}_{5} \mathrm{H}_{6}\right)\right]$ shows an initial weight loss of $-\mathrm{N}_{2} \mathrm{C}_{5} \mathrm{H}_{6}$ moiety at $85.2^{\circ} \mathrm{C}$, (Obs. wt. loss $=11.8 \%$, Calc. wt. loss $=12.1 \%$ ). This is followed by a loss of four $-\mathrm{C}_{6} \mathrm{H}_{5}$ groups at $408.5^{\circ} \mathrm{C}$ (Obs. wt. loss $40.2 \%$, Calc. wt. loss $=39.2 \%)$. And finally at $583.5^{\circ} \mathrm{C}$, the stable oxide of vanadium, that is, $\mathrm{VO}_{2}$ (Obs. wt. loss $89.2 \%$ Calc. wt. loss $=89.3 \%$ ), is formed. Simultaneously, there are some overlapped exothermal peaks on DTA curve in the range of $450-600^{\circ} \mathrm{C}$ corresponding to the major weight loss of the complex especially that the peak on DTA curve at $505^{\circ} \mathrm{C}$ corresponds to the porphyrin skeleton [24].

6.7. Antifungal Activity. From the results found, it has been concluded that on increasing the concentration of the complexes $[\mathrm{VO}(\mathrm{SA} / \mathrm{SSA})]$, the colony diameter of the fungus decreases (Table 4) and hence percent inhibition increases. On doubling, the concentration of the complexes and the percent inhibition also doubles which shows linear relationship between concentration and percent inhibition. The increase in antimicrobial activity is due to faster diffusion of metal complexes as a whole through the cell membrane or due to combined activity effect of the metal and the ligand.

Such increased activity of the metal complexes can be explained on the basis of Overtone's concept [25] and Tweedy's chelation theory [26]. The lipid membrane that surrounds the cell favours passage of only lipid soluble materials due to lipophilicity being an important factor which controls the antimicrobial activity. On chelation, the polarity of the metal ion will be reduced to a greater extent due to overlap of the ligand orbital and partial sharing of the positive charge of the metal ion with donor group.

Antifungal activities of all compounds were studied against one fungal strain (Sclerotium rolfsii). It is concluded that all the synthesized compounds showed overall good activity against this antifungal strain up to $90 \%$. Among these complexes, [VO(SSA)(1,10-Phen)] was found to be more active than other complexes, whereas [VO(tpp)(o-AmPy)] was found to be inactive. 

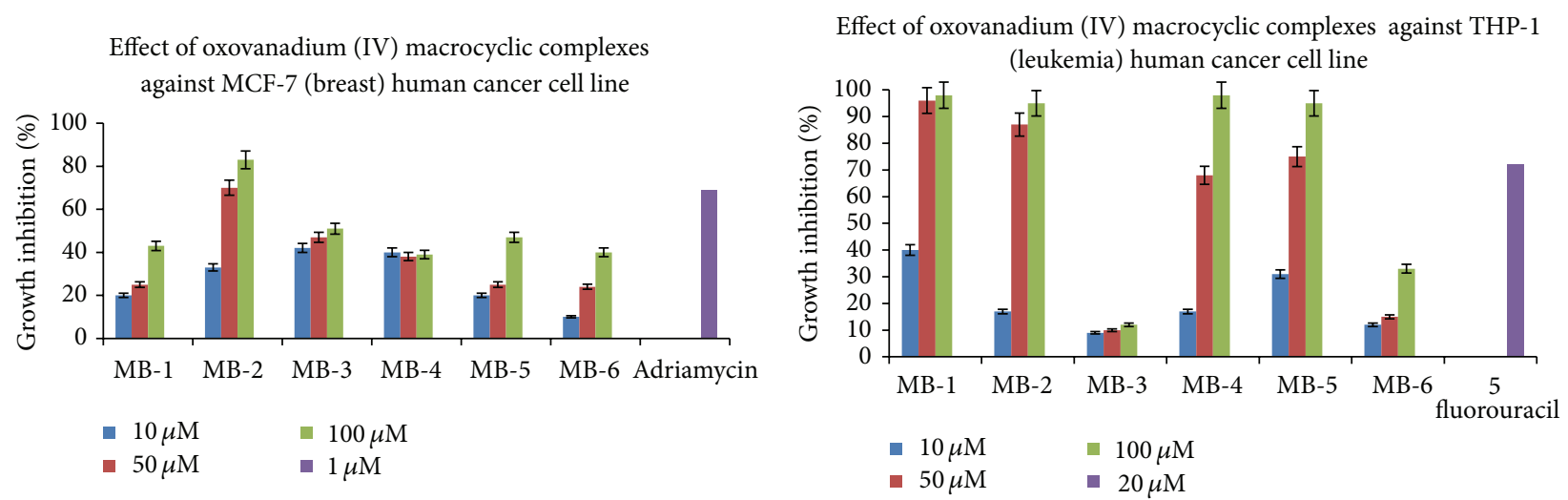

Effect of oxovanadium (IV) macrocyclic complexes against PC-3
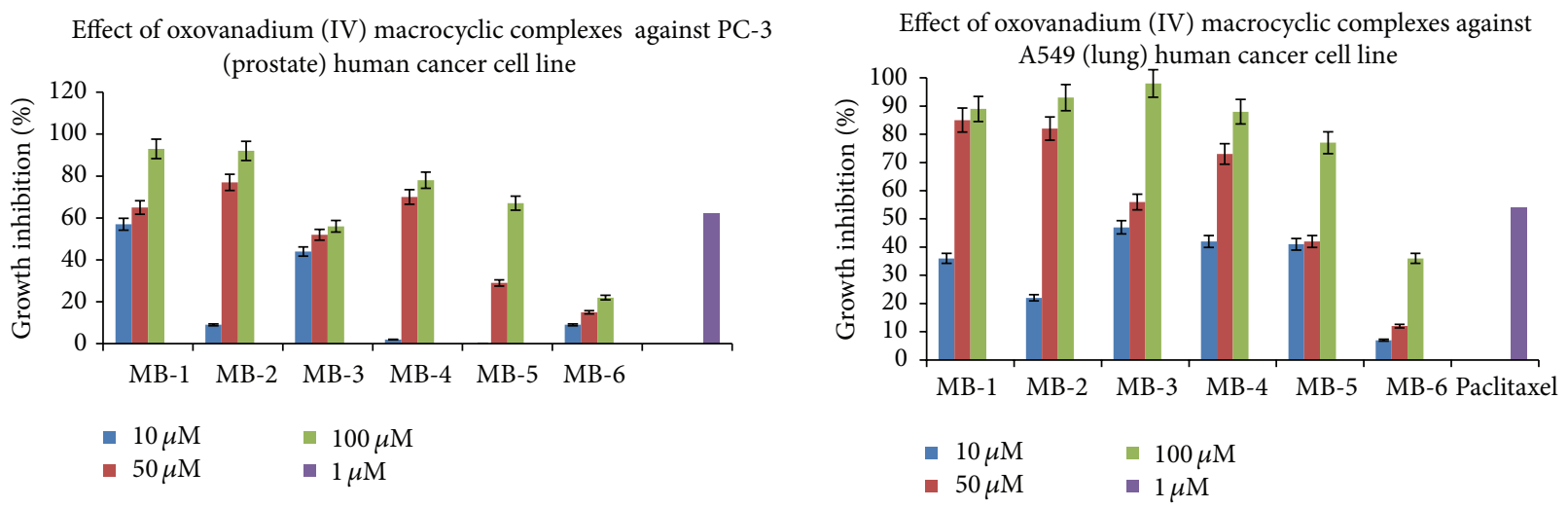

FIgURE 2: In vitro cytotoxicity of oxovanadium(IV) macrocyclic complexes against human cancer cell lines, where MB-1 is [VO(SSA)(o$\mathrm{MePy})_{2}$ ], MB-2 is $\left[\mathrm{VO}(\mathrm{SA})(\mathrm{m}-\mathrm{MePy})_{2}\right], \mathrm{MB}-3$ is $\left[\mathrm{VO}(\mathrm{SSA})(\mathrm{o}-\mathrm{AmPy})_{2}\right], \mathrm{MB}-4$ is $[\mathrm{VO}(\mathrm{SSA})(1,10-\mathrm{Phen})], \mathrm{MB}-5$ is $\left[\mathrm{VO}(\mathrm{SSA})(\mathrm{o}-\mathrm{MePy})_{2}\right]$, and MB-6 is $[\mathrm{VO}(\mathrm{tpp})(\mathrm{o}-\mathrm{AmPy})]$.

6.8. Antibacterial Activity. Antibacterial activity of the synthesized compounds [VO(SSA)(o-MePy $\left.)_{2}\right]$, [VO $(\mathrm{SA})(\mathrm{m}-$ $\left.\mathrm{MePy})_{2}\right]$, [VO(SSA)(o-AmPy $\left.)_{2}\right], \quad$ [VO(SSA)(1,10-Phen $\left.)\right]$ and $[\mathrm{VO}(\mathrm{tpp})(\mathrm{o}-\mathrm{AmPy})]$ was tested by agar-well-diffusion method (Table 5). Each oxovanadium(IV) macrocyclic complex was tested at three concentrations $10^{-3}, 10^{-4}$, and $10^{-5} \mathrm{M}$ against five bacterial strains, namely, Bacillus subtilis, Micrococcus luteus, Staphylococcus aureus, Pseudomonas fluorescens, and Escherichia coli. The antibacterial activity of each compound has been summarized in Table 5. Among all, compound [VO(SSA)(1,10-Phen)] showed the strongest antibacterial activity against all the bacterial strains even to the low concentrations. Compound $[\mathrm{VO}(\mathrm{SA})(\mathrm{m}-$ $\mathrm{MePy})_{2}$ ] was found to be active against all the strains, but only at higher concentration, that is, $10^{-3} \mathrm{M}$. Compound [VO(SSA)(o-AmPy $)_{2}$ ] was found sensitive to B. subtilis, $S$. aureus, and $P$. fluorescens at high concentration, that is, $10^{-3} \mathrm{M}$, whereas compound [VO(SSA)(en)] was found to be active against only $B$. subtilis and P. fluorescens. All the bacterial strains were found to be resistant to compound $\left[\mathrm{VO}(\mathrm{SSA})(\mathrm{o}-\mathrm{MePy})_{2}\right]$ followed by $[\mathrm{VO}(\mathrm{tpp})(\mathrm{o}-\mathrm{AmPy})]$ that showed activity only against $E$. coli (Table 5).

Hence, the results showed that [VO(SSA)(1,10-Phen)] complex shows high potential for antibacterial activity, whereas [Vo(tpp)(o-AmPy)] complex shows the least activity as shown in Table 5.
6.9. In Vitro Cytotoxicity against Human Cancer Cell Lines. Evaluation of in vitro cytotoxicity of oxovanadium(IV) macrocyclic complexes was observed against four human cancer cell lines, namely, breast (MCF-7), leukemia (THP1), prostate (PC-3), and lung (A549) at different concentrations as shown in Figure 2. Dose-dependent percent growth inhibition was observed against all the cancer cell lines. Among the five complexes, [VO(SA)(m$\mathrm{MePy})_{2}$ ] complex showed prominent activity against all the human cancer cell lines. Growth percent inhibition of $\left[\mathrm{VO}(\mathrm{SA})(\mathrm{m}-\mathrm{MePy})_{2}\right]$ complex observed was 70 and 83 against breast, 85 and 95 against leukemia, 77 and 92 against prostate, and 82 and 93 against lung cancer cell at 50 and $100 \mu \mathrm{M}$ respectively (Figure 2$)$. [VO(SSA)(1,10-Phen)] and $\left[\mathrm{VO}(\mathrm{SSA})(\mathrm{o}-\mathrm{MePy})_{2}\right]$ complexes showed prominent activity against three human cancer cell lines, namely, leukemia, prostate, and lung. [VO(SSA)(en)] showed activity against percent growth inhibition against two human cancer cell lines, namely, leukemia and lung, whereas [VO(SSA)(o$\mathrm{AmPy})_{2}$ ] showed activity only against lung cancer cell line at $100 \mu \mathrm{M}$ only (Figure 2). Effect of [VO(tpp)(o-AmPy)] was negligible against all the human cancer cell lines at all the concentrations.

Hence, all the five complexes of [VO(SA/SSA)L/L-L] complex show prominent activity against the human cancer cell lines, whereas complex of vanadium with porphyrin, that 
is, $[\mathrm{VO}(\mathrm{tpp})(2-\mathrm{AmPy})]$, does not exhibit growth inhibition against human cancer cell lines.

\section{Conclusion}

On the basis of the above elemental analysis and spectral studies, confirmed by mass spectra showing characteristic molecular ion peak at their $\mathrm{m} / \mathrm{z}$ value for their monomeric form, square pyramidal structure is proposed for these complexes. Definite structure for the fascinating complexes in solid state would be possible only after X-ray crystallographic studies, which have not been successful so far.

Further few complexes of [VO(SA/SSA)] complex were evaluated for biological activities and it was found that they showed prominent antifungal, antibacterial, and anticancer activity when compared to the porphyrin complex.

\section{Acknowledgments}

The authors are indebted to IIIM Jammu and the Department of Biotechnology, University of Jammu, for providing their help to carry out the bioassays.

\section{References}

[1] R. Sellappan, S. Prasad, P. Jayaseelan, and R. Rajavel, "Synthesis, spectral characterization, electrochemical and antimicrobial activity of macrocyclic schiff base vanadyl complexes," Rasayan Journal of Chemistry, vol. 3, no. 3, pp. 556-562, 2010.

[2] P. Sengupta, R. Dinda, S. Ghosh, and W. S. Sheldrick, "Synthesis and characterization of some biologically active ruthenium(II) complexes of thiosemicarbazones of pyridine 2-aldehyde and thiophene 2-aldehyde involving some ring substituted 4-phenylthiosemicarbazides and 4-Cyclohexylthiosemicarbazide. Crystal Structure of Cis- $\left[\mathrm{Ru}\left(\mathrm{Pph}_{3}\right)_{2}\left(\mathrm{~L}^{6} \mathrm{H}\right)_{2}\right]$ (Clo4)2 $2 \mathrm{H}_{2} \mathrm{O} \quad[\mathrm{L} 6 \mathrm{H}=4$-(Cyclohexyl) Thiosemicarbazone of Pyridine 2-Aldehyde]," Polyhedron, vol. 22, no. 3, pp. 447-453, 2003.

[3] M. A. Pujar, B. S. Hadimani, S. Meenakumari, S. M. Gaddad, and Y. F. Neelgund, "Azo and schiff bases and their metal complexes as antibacterial compounds," Current Science, vol. 55, no. 7, pp. 353-354, 1986.

[4] L. Mishra, A. Jha, and A. K. Yadaw, "Synthesis, spectroscopic and antifungal studies of transition metal trinuclear/ polynuclear complexes with azolo-2,4-pentane-dione: part III," Transition Metal Chemistry, vol. 22, no. 4, pp. 406-410, 1997.

[5] L. J. Mishra, "Chelation and ungitoxicity," Indian Chemical Society, vol. 76, no. 4, pp. 175-181, 1999.

[6] M. Formica, V. Fusi, M. Micheloni, R. Pontellini, and P. Romani, "Cryptand ligands for selective lithium coordination," Coordination Chemistry Reviews, vol. 184, no. 1, pp. 347-363, 1999.

[7] V. Stavila, J. C. Fettinger, and K. H. Whitmire, "Synthesis and characterization of new phenylbis(salicylato)bismuth(III) complexes," Organometallics, vol. 26, no. 14, pp. 3321-3328, 2007.

[8] R. M. Smith, A. E. Martell, and R. S. Motekaitis, NIST Critically Selected Stability Constants of Metal Complexes Database, Version 4.0, Texas A and M University, College Station, Tex, USA, 1997.
[9] A. E. Martell, R. J. Motekaitis, and R. M. Smith, "Aluminium complexes of hydroxyaliphatic and hydroxyaromatic ligands in aqueous systems-some problems and solutions," Polyhedron, vol. 9, no. 2-3, pp. 171-187, 1990.

[10] T. K. Saha, Y. Yoshikawa, H. Yasui, and H. Sakurai, “Oxovanadium(IV)-porphyrin complex as a potent insulin-mimetic. Treatment of experimental type 1 diabetic mice by the complex [meso-tetrakis(4-sulfonatophenyl)porphyrinato] oxovanadate(IV)(4-)," Bulletin of the Chemical Society of Japan, vol. 79, no. 8, pp. 1191-1200, 2006.

[11] H. Sakurai, T. Inohara, Y. Adachi, K. Kawabe, H. Yasui, and J. Takada, "A new candidate for insulinomimetic vanadium complex: synergism of oxovanadium(IV)porphyrin and sodium ascorbate," Bioorganic and Medicinal Chemistry Letters, vol. 14, no. 5, pp. 1093-1096, 2004.

[12] A. D. Longo, F. R. Longo, J. D. Finarelli, J. Goldmacher, J. Assour, and L. Korsakoff, "A Simplified Synthesis for mesotetraphenylporphine," The Journal of Organic Chemistry, vol. 32, no. 2, pp. 476-476, 1967.

[13] A. R. Menotti, "Porphyrin studies. IV. 1 The Synthesis of $\alpha, \beta, \gamma, \delta$ Tetraphenylporphine," Journal of the American Chemical Society, vol. 63, no. 1, pp. 267-270, 1941.

[14] J. M. Vincent, "Distortion of fungal hyphae in the presence of certain inhibitors," Nature, vol. 159, p. 850, 1927.

[15] F. Oke, B. Aslim, S. Ozturk, and S. Altundag, "Essential oil composition, antimicrobial and antioxidant activities of Satureja cuneifolia Ten," Food Chemistry, vol. 112, no. 4, pp. 874-879, 2009.

[16] A. Thiantanawat, B. J. Long, and A. M. Brodie, "Signaling pathways of apoptosis activated by aromatase inhibitors and antiestrogens," Cancer Research, vol. 63, no. 22, pp. 8037-8050, 2003.

[17] X. Tong, S. Lin, M. Fujii, and D. X. Hou, "Echinocystic acid induces apoptosis in HL-60 cells through mitochondriamediated death pathway," Cancer Letters, vol. 212, no. 1, pp. 2132, 2004.

[18] S. Singh, D. P. Rao, A. K. Yadava, and H. S. Yadava, "Synthesis and characterisation of oxovanadium (IV) complexes with tetradentate schiff base ligands having thenil as precursor molecule," Current Research in Chemistry, vol. 3, no. 2, pp. 106$113,2011$.

[19] R. Murugavel and R. Korah, "Structural diversity and supramolecular aggregation in calcium, strontium, and barium salicylates incorporating 1,10-phenanthroline and 4,4'-bipyridine: probing the softer side of group 2 metal ions with pyridinic ligands," Inorganic Chemistry, vol. 46, no. 26, pp. 11048-11062, 2007.

[20] E. Akalin and S. Akyuz, "The FT-IR spectroscopic investigation of transition metal(II) 4-aminopyridine tetracyanonickelate complexes," Journal of Molecular Structure, vol. 482, pp. 171-174, 1999.

[21] V. K. Monga, K. H. Thompson, V. G. Yuen et al., "Vanadium complexes with mixed O,S anionic ligands derived from maltol: synthesis, characterization, and biological studies," Inorganic Chemistry, vol. 44, no. 8, pp. 2678-2688, 2005.

[22] Z.-C. Sun, Y.-B. She, Y. Zhou, X.-F. Song, and K. Li, "Synthesis, characterization and spectral properties of substituted tetraphenylporphyrin iron chloride complexes," Molecules, vol. 16, no. 4, pp. 2960-2970, 2011. 
[23] E. J. Baran, A. H. Jubert, and E. G. Ferrer, "Infrared, raman and pre-resonance raman spectra of vanadyl(1V) tetraphenylporphyrin," Journal of Raman Spectroscopy, vol. 23, pp. 489494, 1992.

[24] N. Dharmaraj, P. Viswanathamurthi, and K. Natarajan, "Ruthenium(II) complexes containing bidentate Schiff bases and their antifungal activity," Transition Metal Chemistry, vol. 26, no. 1-2, pp. 105-109, 2001.

[25] C. Zhuang, X. Tang, D. Wang et al., "An unsymmetrical porphyrin and its metal complexes: synthesis, spectroscopy, thermal analysis and liquid crystal properties," Journal of the Serbian Chemical Society, vol. 74, no. 10, pp. 1097-1104, 2009.

[26] L. Mishra and V. K. Singh, "Synthesis, structural and antifungal studies of $\mathrm{Co}(\mathrm{II}), \mathrm{Ni}(\mathrm{II}), \mathrm{Cu}(\mathrm{II})$ and $\mathrm{Zn}(\mathrm{II})$ complexes with new schiff bases bearing benzimidazoles," Indian Journal of Chemistry, vol. 32, no. 5, pp. 446-457, 1993. 

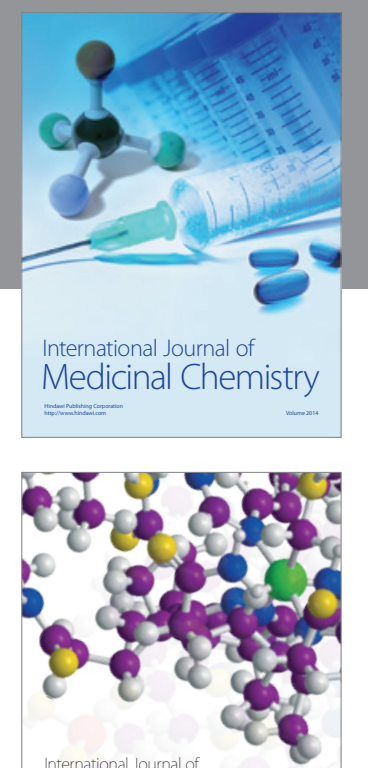

\section{Carbohydrate} Chemistry

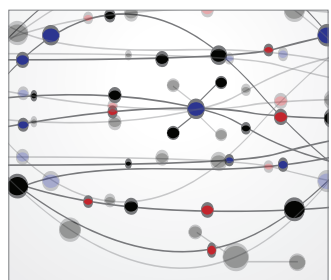

The Scientific World Journal
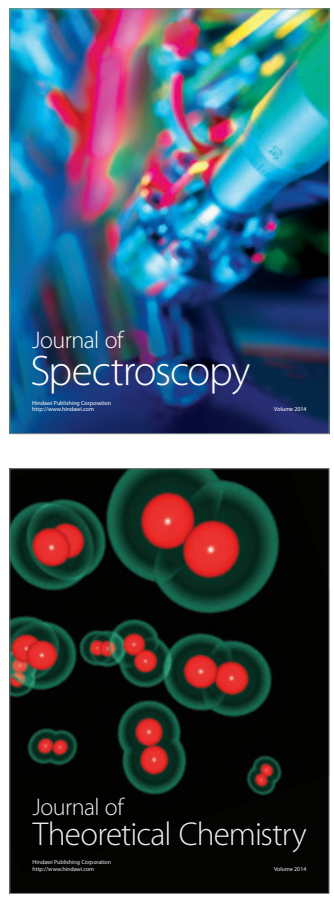
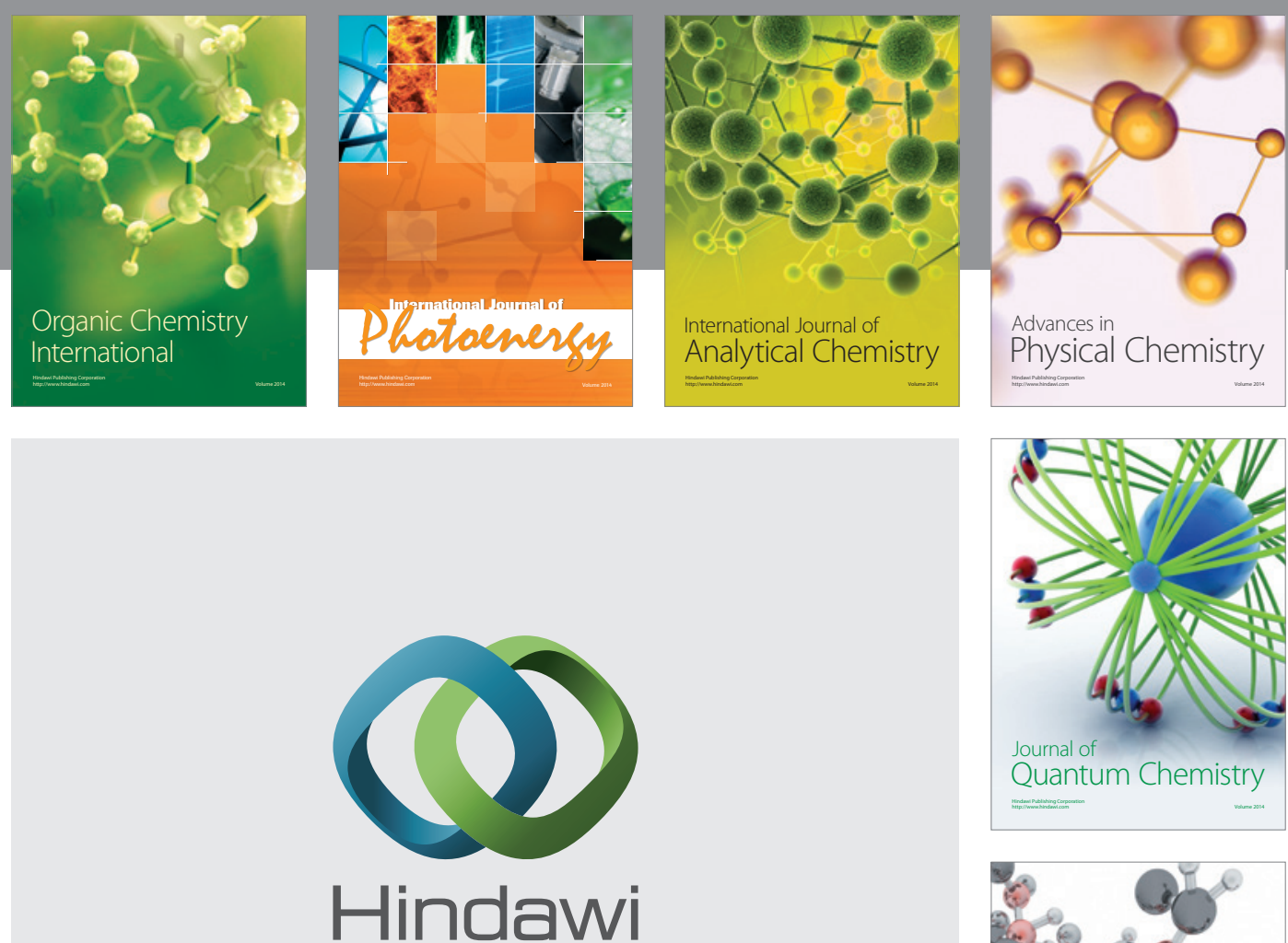

Submit your manuscripts at

http://www.hindawi.com

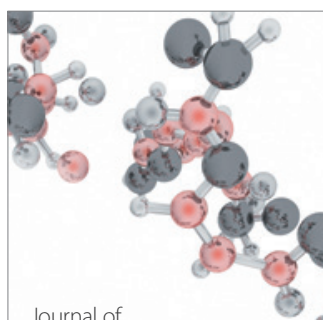

Analytical Methods

in Chemistry

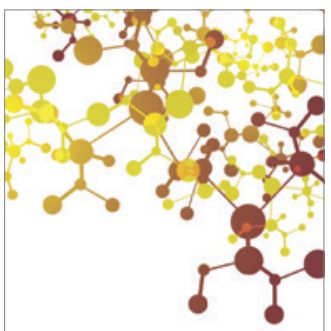

Journal of

Applied Chemistry

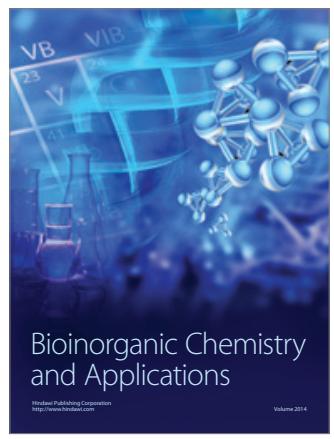

Inorganic Chemistry
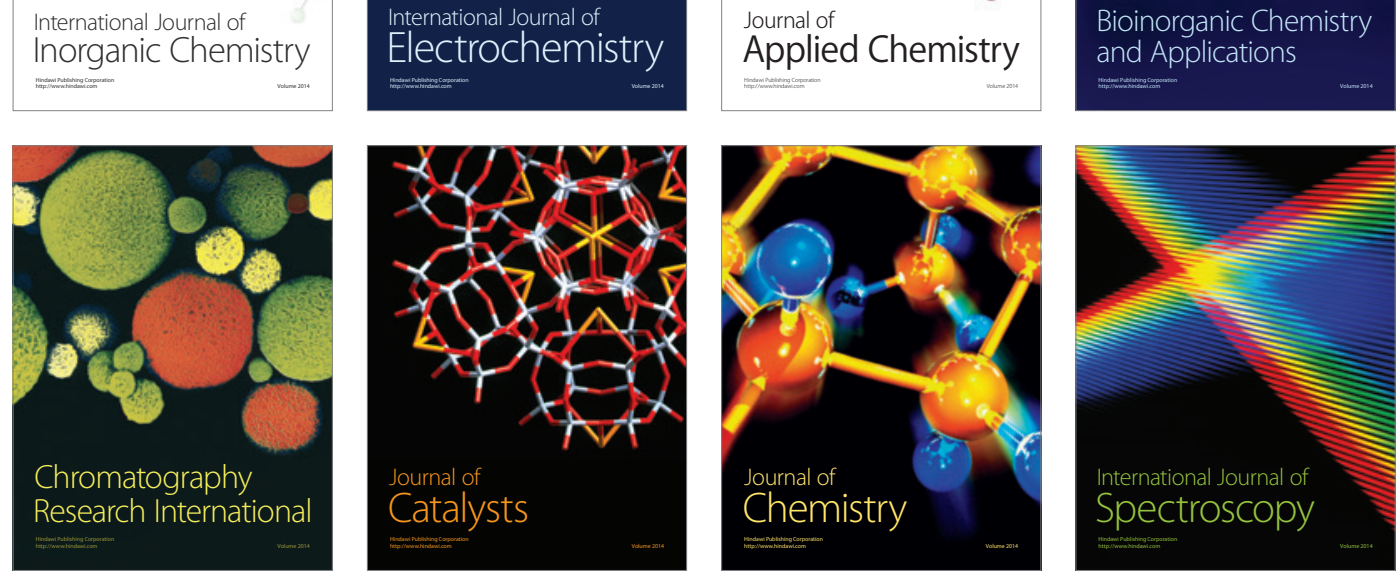